\title{
İktidar, Bellek ve Sinema
}

\author{
Burak Medin 1
}

\begin{abstract}
Öz
Bu çalışmada temel olarak tarih, bellek ve iktidar ilişkisine odaklanıldı. Bu ilişkinin ortaya konulacağı ve bu minvalde bir tartışmanın yürütüleceği zemin ise sinemadır. Bellek üzerine üretilen teorilerden hareketle filmlerle ve filmik öğelerle iletişime geçilebilir. Bu bağlamda teorinin somutlaşabilmesi yani pratiğe dönüşebilmesi ayrıca tarih, bellek ve iktidar arasındaki çok boyutlu ilişkinin anlaşılabilir hale gelebilmesi de filmler aracılığıyla mümkün olabilmektedir. Jan Assman'ın ve Paul Connerton'ın bellek üzerine üretmiş olduğu kavramları filmler üzerinden düşünmek ve bir tartışma yürütmek bu bağlamda önem taşır. Bu kavramlar tarih, bellek ve iktidar arasındaki ilişkinin anlaşılmasına olanak tanır. İletişimsel ve kültürel bellek kavramları dışında bu ilişkinin daha iyi anlaşılabilmesi adına resmi tarih ve sözlü tarih kavramlarının da tartışmaya dâhil edilmesi gereklidir. Bu bağlamda bu çalışmada belleğin iktidar karşısındaki konumu, bellek türlerinin inşası ve kişisel belleğin alternatif bir tarihyazımı noktasındaki potansiyeli Başkanın Adamları filmi temelinde ele alındı ve tartışıldı. Kavramsal tartışmanın yanı sıra imajların gösteren ve gösterilen ilişkisini yorumlamak adına göstergebilim, anlatıdaki söylemin bağlamını incelemek adına ise söylem çözümlemesi (sözdizimsel bir eksende) yöntem olarak tercih edildi. Kuram ve yöntem ekseninde yapılan çözümlemede anlatıdaki iktidarın kendi varlığını devam ettirebilmek adına medyayı kullanarak resmi tarihi inşa ettiği, bu kurgulanmış gerçekliği inşa ederken iletişimsel ve kültürel belleğin yanı sıra nesneler belleğini de dönüştürdüğü tespit edildi.
\end{abstract}

Anahtar Kelimeler: Sinema, İktidar, Bellek, Resmi Tarih.

Atıf: Medin, B. (2019). Iktidar, Bellek ve Sinema. Akdeniz Üniversitesi İletișim Fakültesi Dergisi, Haziran (31), s. $123-146$

1 Dr. Öğr. Üyesi. Erciyes Üniversitesi, İletişim Fakültesi, Radyo Televizyon ve Sinema Bölümü, burakmedin@hotmail.com, ORCID: 0000-0001-8012-035X. 


\title{
Power, Memory and Cinema
}

\begin{abstract}
This study focuses mainly on the relationship between history, memory and power. This relationship is mainly discussed on the cinema axis. Based on the theories produced on memory, film and film elements can be contacted. In this context, it is possible for the theory to be practical and the multidimensional relationship between history, memory and power to be understandable through films. It is important to think about the concepts of memory produced by Jan Assman and Paul Connerton over films and to carry out a discussion. Memory concepts (communicative and cultural memory) enable an understanding of the relationship between history, memory and power. In addition to these concepts, in order to better understand the relationship, official history and oral history concepts should be included in the discussion. In this study, the position of memory in the face of power, the construction of cultural and communicative memory, the potential of personal memory in an alternative historiography point and the role of oral history are discussed on the basis of Wag The Dog (1998) film. Besides conceptual discussion, semiotics and discourse analysis were preferred. In the analysis made on the axis of the theory and method, it was determined that the power built the official history by using the media to maintain its position and transformed communicative, cultural and objects memory.
\end{abstract}

Keywords: Cinema, Power, Memory, Official History.

\section{Giriș}

$\mathrm{B}$ ellek, birçok disiplin için önemli çalışma alanlarından biridir. Her bilim, bu kavramın farklı yönlerine odaklanır. Bellek kimi zaman yitirilen ve tekrar ulaşılmaya çalışılan bir arayış çabası olarak somutlaşır, kimi zaman bireyin ve toplumların devraldığı ve devrettiği bir hafızadır, bazı zamanlar ise unutulmaya çalışılan trajik bir olaydır. Bazı ülkeler ve toplumlar için ise bellek, iktidarların belirli ideolojileri ve amaçları bağlamında inşa edilen bir üretim olarak ortaya çıkar. Bir inşa olarak bellek, bireyin ve toplumun her anına sirayet eder. Bireyi ve toplumu, gündeme dair olan ideoloji bağlamında biçimlendirir ve şekillendirir. Bu şekillendirme ve biçimlendirme sadece yaşanılan o ana dair değildir. Biçimlendirme hem geçmişe hem de geleceğe yöneliktir. Bu bağlamda o topluma yönelik hem ulusal hem de uluslararası tarihin despotik iktidarların gözetiminde ve tahakkümünde bir şekle girdiğini söylemek yanlış olmayacaktır. Bu durum, farklı disiplinler dâhil edilerek araştırılması gereken konuların başında gelir. Bu çalışma bu sorunsaldan ve belleğin -kimi zaman- iktidarlar tarafından var olan gerçeklikten uzaklaştırılarak bir yapıntı olarak inşa edildiği varsayımından hareketle filmsel imajlar ve söylemler üzerinden tarih, bellek ve iktidar arasındaki ilişkiye odaklanmaktadır.

Bellek üzerine literatürde çeşitli çalışmalar ve teoriler mevcuttur. Bu çalışmada kapsam ve sınırlılık çerçevesinde Jan Assman'ın (2001) ve Paul Connerton'un (1999) farklı 
anlarda üretmiş oldukları iletişimsel/kişisel ve kültürel/toplumsal bellek kavramlarından yararlanıldı. Bu kavramlardan hareketle filmsel imajlar ve söylemler üzerinden bellek ve iktidar ilişkisine yönelik bir düşünme ve bir tartışma yürütüldü. Böylece hem bu düşünürlerin teorilerini somutlaştırabilmek hem de filmler aracılığıyla tarih, bellek ve iktidar arasındaki bu çok boyutlu ilişkinin anlaşılabilmesi mümkün olabildi. Bu çok boyutlu ilişkinin daha iyi okunabilmesi amacıyla bu kavramların dışında resmi tarih ve sözlü tarih kavramları da filmsel düşünmeye dâhil edildi.

Bu çalışma sözlü tarih temelli bir çalışma değildir. Bellek ve iktidar arasındaki ilişkiyi filmsel imajlar üzerinden düşünürken, sözü de önemli bir eyleyen olarak ele alan ve bu bağlamda iletişimsel belleğin yapıntı tarih karşısındaki önemli rolünü ortaya koymaya çalışan film temelli bir çalışmadır. Bellek ve iktidar arasındaki ilişkiyi filmsel imajlar üzerinden anlamaya çalışırken resmi tarih ve sözlü tarih arasındaki ayrımın kavranması önem taşıdığından sözlü tarihe önemli bir bölüm ayrıldı. Bir veri toplama tekniği ve bir araştırma yöntemi olarak sözlü tarihin genel hatları çizildi, resmi tarihle olan ilişkisi üzerinde duruldu. Daha fazla tarih anlayışı ekseninde sözlü tarihin potansiyeli ortaya konulmaya çalışıldı. Buradaki temel amaç kimi zaman resmi tarihin bir yapıntı olabileceği düşüncesini filmsel imajlar üzerinden ortaya koymak ve kimi zaman belirli ideolojiler bağlamında inşa edilerek çarpıtılan tarihsel gerçekliğin, söz temelli iletişimsel belleğin sahip olduğu potansiyelle yanlışlanabileceğinin altını çizebilmektir. Ayrıca söz temelli bir determinizme kaymadan ve o döneme dair olan belleği aşkın hale getirmeden gerçeklik ve inşa arasındaki ayrımın anlaşılabilmesinde sözün önemine vurgu yapabilmektir.

Tarih, bellek ve iktidar arasındaki ilişkiyi anlayabilmek adına ele alınan araştırma nesnesi üzerinden birtakım araştırma soruları üretildi. Bu sorulara verilen cevaplar bu çalışmanın temel izlencesini oluşturdu: 1- Ele alınan araştırma nesnesi bağlamında iletişimsel ya da kültürel bellek, iktidarın toplumu denetleme ve gözetleme noktasında tercih ettiği hegemonik bir araç olarak mı işlev görmektedir? 2-Film anlatısında inşa edilen kültürel bellek karşısında iletişimsel belleğin önemi nedir? 3-illetişimsel belleği harekete geçiren nesneler belleği, anlatıdaki iktidarın kendi resmi tarihini yazma noktasında nasıl bir etkiye ve role sahiptir? 4-Anlatıdaki iktidarın kendi ideolojisini inşa etme ve bu ideolojinin devamlılığını sağlama noktasında tasarladığı yapıntı resmi tarih karşısında iletişimsel belleğin (o ana tanık olan belleğin) alternatif bir tarih yazımı noktasındaki potansiyeli nedir?

Çizilen tüm bu kuramsal çerçeve ekseninde bu çalışmada belleğin iktidar karşısındaki konumu, kültürel ve iletişimsel belleğin inşası, kişisel belleğin alternatif bir tarihyazımı noktasındaki potansiyeli, sözlü tarihin daha fazla tarih anlayışı eksenindeki rolü ve resmi tarihyazımı ile medya arasındaki ilişki "Başkanın Adamları" (Wag the Dog-1998) filmi temelinde ele alındı ve tartışıldı. Bu filmin araştırma nesnesi olarak ele alınmasındaki temel amaç, filmin sinemasal imajlar ve söylemler üzerinden inşa edilen yapıntı resmi tarihi ifşa etme potansiyelidir. Ayrıca ele alınan filmin, bellek teorisini tartışma ve örnekleme noktasında önemli veriler sunacağı düşünülmektedir. Bellek, iktidar ve sinema arasındaki ilişkiyi tartışmak ve somutlamak adına kavramsal tartışmanın yanı 
sıra iki temel film çözümleme yöntemi kullanıldı: Göstergebilim ve söylem çözümlemesi. Göstergebilim imajların gösteren ve gösterilen ilişkisini yorumlamak ve yan anlamları ortaya koyabilmek, söylem çözümlemesi ise film anlatısının çerçevelendiği dilin derin yapısını anlayabilmek adına tercih edildi. Söylem çözümlemesi Van Dijk'ın (2000, s.61) belirttiği üzere standart ve tek bir yol sunmaz. Film çalışmalarında farklı biçimlerde kullanılan bu yöntemde araştırmacı, film metninde hangi noktayı öne çıkarmak istiyorsa bu yöntemden arzu ettiği bağlam içinde yararlanır. Bu çalışmada söylem çözümlemesi ile söylemin bağlamını incelemek, imaları detaylı bir çerçeve içinde okumak, olumlu ve olumsuz görüşleri/anlamları ben/öteki ekseninde ortaya çıkarmak ve güç ilişkilerini analiz etmek amaçlandı.

\section{Bellek Üzerine Kuramsal Bir Tartıșma}

Bellek denildiği zaman insanın aklına gelen ilk düşünce (Assman, 2001, s. 24) belleğin beyinle ilgili olduğudur. Bu bağlamda bellek, sadece psikoloji ve nöroloji gibi disiplinlerin alanı içinde değerlendirilir. Fakat bu bakış açısı yüzeysel kalarak belleğin neleri içerdiği, içerikleri nasıl organize ettiği ve kültürel bağlamdan nasıl etkilendiği gibi soruların da cevapsız kalmasına neden olmaktadır. Assman'ın (2001) ve Connerton'un (1999) birbirinden bağımsız yaptıkları çalışma ise bellek kavramını bu sıkışık alandan çıkarır ve belleğin daha derin bir bakış açısıyla yorumlanmasının önünü açar.

Assman belleğin dört farklı boyutunu ele alır (2001, s. 25-62). Ona göre bellek "mimetik", "nesneler", "iletişimsel” ve "kültürel' olmak üzere dört farklı boyuttan oluşur. Davranışa ait bir bellek türü olan mimetik bellek, çoğunlukla taklit etme geleneğine bağlıdır. Ona göre bu davranışın içinde alışkanlıklar ve kurallar söz konusudur. Mimetik bellek türüne dair şu örnekler verilebilir: Kullanım kılavuzları, inşa planları, yemek kitapları vb. Nesneler belleği, bir belleğin harekete geçebilmesi ve daha detaylı bir şekilde geçmişin ortaya konabilmesi adına son derece önem taşır. İnsanlar ilk günden bu yana birtakım nesneleri kullanır. Bu nesneler çoğunlukla insanları yansıtır niteliklere sahiptir. İnsanın kullandığı takılar, giysiler, kitaplar, iletişim araçları vb. zamanla insanı tanımlayan bir dile sahip olur. Kullanılan bu nesneler, belleğin canlanmasına ve geçmişe bir yolculuk yapılabilmesine yardımcı olabilir. Sözlü tarih çalışmalarında nesneler belleğinin harekete geçebilmesi son derece önem taşır. Konuşulan zamana dair bir fotoğraf, bir haber ya da o döneme dair herhangi bir nesne hatıraların akla gelmesine ve olayların detaylandırımasına olanak tanır. Nesneler dolayımından geçen bellek böylece canlanabilir.

Sinemada nesneler belleğinden sıklıkla yararlanır. Hangi anlatı kodlarına sahip olursa olsun özne konumundaki kahramanın izlencesinin başlayabilmesinde ya da izlencenin farklı bir yöne doğru çevrinmesinde, kahramanın değişim ve dönüşüm içine girmesinde nesneler dolayımından geçen belleğe önemli bir rol verilir. Bu duruma örnek olarak James Cameron'ın 1997 yapımı Titanic filmi örnek gösterilebilir. Anlatı, araştırma gemisinin Okyanusun Kalbi ismi verilen elmas kolyeyi arayış kesitleriyle başlar. Titanic'ın enkazında bulunan bir sandıktan çıkan eski bir resimle birlikte yaşlı Rose anlatıya dâhil olur. Resmin dışında enkazdan çıkarılan nesneler arasında Rose'un 
kullanmış olduğu ayna ve toka da vardır. Yaşlı Rose geçmişe olan yolculuğunu resim, ayna ve toka gibi nesneler dolayımından geçerek başlatır. Enkazdan çıkarılan fotoğrafla ilk karşılaştığında resmin yapıldığı o ana geri dönen Rose'un 84 yıl önceki belleği canlanır. Araştırma gemisinin enkazı gösteren kamera görüntüleri de nesneler belleğini harekete geçirir, böylece Rose tekrar Titanic içinde salınmaya ve o anı yaşamaya başlar. Bu örnekler farklı film anlatıları üzerinden çoğaltılabilir. Örneğin Issız Adam (2008) filminde nesneler belleğinin harekete geçmesi Titanic filmindeki gibi yaşanan trajik bir olayın canlanmasından farklı özellikler taşır. Issız Adam filminde Alper'in Ada'nın tokasını bulmasıyla nesneler dolayımından geçen bellek, bir ayrılığın ardından yaşanamayan yas sürecini başlatır. Öztürk (2010, s. 212), Ada'nın değerini hemen kavrayamayan Alper'in bir nesne aracılığı ile anılarının canlandığını ve kanonikleştiğini belirtir. Nesne ve bellek arasındaki ilişkiyi Issız Adam filmindeki (2008) Alper'in şu sözleri üzerinden sabitlemek mümkündür:

\begin{abstract}
"Senden ayrıldığım ilk günler kuş gibi hissetmiştim kendimi. Sana da kendime de iyilik yaptığımı düşünmüştüm. Ta ki ufacık bir şey beni darmadağın edene kadar. Sana ait ufacık bir şey alay etti benimle o gün. İşte o sabah seni ve neleri kaybettiğimi anladım. Bir daha sen olmayacaktın. Bir daha bunu yaşayamayacaktım ben bir başkasıyla. Sana benzeyen yüzler, kokuna benzeyen kokular, sesine benzer sesler çıkardı karşıma. Ya da bana mı öyle geldi ne. Bilmem. Biliyor musun, bir gün nerede kaybettiğini bilmediğin o küçük saç tokası hala cebimde durur”.
\end{abstract}

Assman'ın bir diğer önemli bellek türü iletişimsel bellektir. Sözlü tarihin de yararlandığı ve bu çalışmanın sıklıkla üzerinde durduğu en önemli bellek türlerinden biri olan iletişimsel bellek, bireyin diğer insanlarla yaşadığı etkileşim ve iletişim aracılığı ile var olur. İletişimsel bellek, kişinin yakın geçmişine dair kişisel anılarıdır. Burada kuşağa özgülük merkezi konumdadır. Bu anılar da bireyin diğerleriyle girdiği etkileşim sonucu ortaya çıkar, kişi bunları çağdaşlarıyla paylaşır. Burada önemli olan bu belleğin zamanla oluşması ve o belleği taşıyanların hayatlarının son bulmasıyla da ortadan kalkmasıdır. Yani iletişimsel bellek, taşıyıcılarıyla sınırlıdır. Bellek ve iktidar arasındaki ilişkide iletişimsel bellek, kilit bir rol oynar. Belirli bir ideoloji ekseninde üretilen bir yapıntı tarih var ise bu durumu yanlışlamak, iletişimsel belleğin varlığı ile mümkün olabilir. Bu bağlamda gerçekliğin ortaya çıkmasında iletişimsel belleğin önemli bir potansiyeli söz konusudur. Assman'ın son bellek türü, kültürel bellektir. Taklitler ve davranışlar, gelenek statüsü kazandığında kültürel bellekten bahsedilir. Bu bellek türünde kültürel anlamlar birtakım yollarla (mezar taşları, anıtlar, tapınaklar gibi somut nesneler aracılığıyla ya da bayram ritüelleri, folklor gibi canlandırmaya dayalı edimlerle) devredilir. Kültürel bellek kısaca kurumlaşmış, biçimlendirilmiş ve törensel bir bellektir. Tarih, bellek ve iktidar eksenindeki ilişkiyi anlamak adına kültürel bellek önemli veriler sunabilir; çünkü despotik bir iktidar kendi ütopyasını inşa ederken diğerleri adına distopik bir dünya tasarımı içine girmiş olabilir. Bu bağlamda kültürel bellek unsurları, bu iktidarın ideolojisinin özelliklerini sergilerken aslından uzaklaşabilir. Bu minvalde o toplum içinde var olan birtakım unsurlar, aslından uzağa düşerek ideolojikleşebilir. Bu durumda iletişimsel bellek devreye girebilir. İletişimsel bellek, aslından uzaklaşan kültürel belleğin yeniden aslına uygun hale getirilmesinde ya da var olan durumun bir 
yapıntıdan ibaret olduğunun gösterilmesinde önemli bir eyleyen olarak tercih edilebilir.

İletişimsel ve kültürel bellek arasındaki farkları anlamak adına aşağıdaki tablodan yararlanmak mümkündür. İki bellek arasındaki farkı kavrayabilmek, film anlatıları üzerinden yapılacak olan tartışmayı anlayabilmek adına önem taşır.

Tablo 1. İletişimsel ve Kültürel Bellek Arasındaki Farklar

\begin{tabular}{|l|c|c|}
\hline İçerik & İletişimsel Bellek & Kültürel Bellek \\
\hline Biçim & $\begin{array}{c}\text { Bireysel biyografiler çerçevesinde } \\
\text { tarihsel deneyimler }\end{array}$ & $\begin{array}{c}\text { Efsanevi köken tarihi, ulaşılamaz } \\
\text { geçmişte yaşananlar }\end{array}$ \\
\hline Araçlar & $\begin{array}{c}\text { Gayrı resmi, az biçimlendirilmiş, } \\
\text { doğal, iletişimsel alışveriş içinde } \\
\text { gelişen, gündelik }\end{array}$ & $\begin{array}{c}\text { Planlanmış, çok iyi biçimlendirilmiş, } \\
\text { törensel iletişim, bayram }\end{array}$ \\
\hline Zaman Yapısı & $\begin{array}{c}\text { Organik belleklerdeki canlı anılar, } \\
\text { deneyler, aktarılanların anlatımı }\end{array}$ & $\begin{array}{c}\text { Kesin nesneleştirme, söz, görüntü } \\
\text { ve dans yoluyla geleneksel sembolik } \\
\text { kodlamananla sahneleme }\end{array}$ \\
\hline Taşıyıcılar & $\begin{array}{c}\text { Belirsiz, bir hatılıma grubunun } \\
\text { canlı tanıkları }\end{array}$ & $\begin{array}{c}\text { Kesin geçmiş, efsanevi bir geçmiş } \\
\text { zaman }\end{array}$ \\
\hline
\end{tabular}

Assman gibi Connerton'un da (1999, s. 25-40) bellekle ilgili kavramsallaştırmaları söz konusudur. Connerton'a göre "toplumsal bellek" denilen şey tarihin yeniden kurulmasından farklı bir süreçtir. Geçmişteki insani etkinliklerin bilgisine de insanların bıraktıkları izlerden yola çıkarak ulaşılabilir. Toplumsal bellek, tarihi yeniden kurma pratiği olarak ele alınabilir. Connerton'un "kişisel bellek" kavramı Assman'ın iletişimsel bellek kavramıyla benzerlik taşır. Kişisel bellek türünde kişisel bir geçmişe gönderme söz konusudur. Bir kişi şu zamanda şu yerde şunları yaptım dediği an, kişisel belleğine başvurmuş demektir. Şiirlerin dizelerini, öyküleri, matematik denklemlerini, şarkıları, mantıksal doğruları içeren bellek türü "bilişsel bellektir". Bilişsel belleği harekete geçirebilmek için geçmişte bir şeylerin öğrenilmiş olması gerekir. "Alışkanlık belleğı" belli bir uygulayımı yeniden ortaya koymakla ilgilidir. Örneğin nasıl yazılacağının, nasıl yüzüleceğinin, nasıl bisiklete binileceğinin ya da bir tenis topuna nasıl vurulacağının anımsanması ve gereken durumlarda bunların yapılabilmesi, alışkanlık belleğinin harekete geçirilmesiyle ilişkilidir.

\section{Tarih ile Söz Ilișkisi}

Tarihin yüzyılın ikinci yarısı itibariyle bilimselleşmeye başlamasıyla 19. yüzyıla kadar birlikteliğini koruyan tarih ile söz ilişkisi kopmaya başladı. Pozitivist metodolojiye öykünen tarih, fen bilimlerinin araştırma nesnesiyle kurduğu ilişkinin benzerini belge ve arşiv ile kurmaya çalıştı. Belgeye dayanmanın bilimselliğin en önemli kriteri olarak gören tarih, belgesiz tarih yazılamayacağını varsaydı. Bu eksende tarih, söz ile olan bağlarını kopardı. Sözlü kaynak kullanımını bilim dışı kabul etti ve kendine özgü yöntemleri olan bağımsız bir araştırma alanı haline geldi. 
Alman tarihçi Ranke ile 19. yüzyılda bilimsel bir iddia kazanmış olan modern tarihyazımı, özellikle ulus devletlerin kuruluş sürecinde geliştirilen üst-anlatılar nedeniyle milletdevlet tarihine indirgendi. Kamusal alanı kapsayan belge ve arşiv temelli çalışma tarihçiliğin esası olarak görüldü. Sıradan insanların sesleri, sözleri, tanıklıkları ve yorumları dışarıda kaldı. Kralların, devlet ve siyaset ekseninde komutanların kısaca büyük adamların yaşam öyküleri ya da onların başrolü oynadığı savaşların tarihi, tarihin temel konusu haline geldi. Ulus-devletlerin yükseldiği bu yüzyılda eski çağlardan bu yana tarihyazımının önemli bir dalı olan siyasi tarih, daha da önem kazandı. 19 . yüzyılın sonlarına doğru ise devlet ve siyaset merkezli tarihyazımı anlayışı eleştirilmeye başlandı. Siyasi olaylar ve devlet adamları üzerine yoğunlaşan anlayış sorgulanmaya ve toplumun, ekonominin ve kültürün rolüne daha fazla önem veren yaklaşımlar ortaya çıkmaya başladı. 20. yüzyılla birlikte söz ve anlatı tekrar tarihin çalışma alanı içine girdi. Bundan böyle tarih; yalnızca savaşların, askeri zaferlerin, çatışmaların, büyük devlet adamlarının, kralların, devrimlerin bir kaydı olmaktan çıktı. Yeni tarihçilik anlayışı alttan tarih yazımına göre yeniden şekillendi. Tarihin çalışma alanı oldukça genişledi ve daha önceden tarihçilerin pek ilgi duymadıkları konular tarihyazımının parçası olmaya başladı. Böylece sıradan insanın tarihi yazılmaya başlandı. Halk kültürü, popüler kültür gibi kavramlar gündelik yaşama odaklanılarak anlaşılmaya başlanırken, tarihçilik anlayışı içerisinde düşünülmesi bile imkânsız konular başlı başına tarih araştırması konusu haline geldi (Öztürk, 2014, s. 45-55; Merz, 2000, s. 31; Okumuş, 2014, s. 35-36; Gökdemir, 2014, s. 199-222; Tosh, 2013, s. 203; Thompson, 1999, s. 2-3; Danacıoğlu, 2012, s. 1-30; İlyasoğlu, 2006, s. 15, Burke, 1993, s. 3-6; Şahin, 2004, s. 112; Metin, 2002, s. 288; Yüceer, 2005, s. v).

20. yüzyılla birlikte tarih, (Danacıoğlu, 2012, s. 2) siyaset merkezli olmaktan toplum merkezli olmaya doğru bir yönelim içine girdi. Antropoloji, sosyoloji gibi disiplinlerin Annales gibi akımların etkisi ile sosyal bilim temelli bir eksene oturdu. 20. yüzyılın başlarından itibaren resmi tarihin yanında sözlü ve görsel tarihe bir yönelim oldu. Devlet ve siyaset merkezli bu geleneksel paradigmaya karşı Burke'in de (1993, s. 3-6) ifade ettiği gibi tüm insanlık eylemlerini tarihin içine dâhil eden, geçmişteki çeşitli ilişkileri ortaya çıkaran tarihin alttan yazımı anlayışının giderek öneminin arttığı alternatif tarihyazımları ortaya çıktı. Alternatif tarihyazımlarından biri olan sözlü tarih, belli bir döneme ait kişisel tanıklık ve/veya yaşantıların belleğin derinliklerinden çıkarılıp değerlendirilmesi yoluyla toplumların tarihlerinin inşasına katkıda bulunan bir araştırma yöntemidir. Öztürkmen'e göre (2011, s. 53) "hayat hikâyeleri üzerinden geçmişi anlamaya ve bugünü yorumlamaya yönelik bir yaklaşım"dır. Sözlü tarih Tosh'un (2013, s. 206-226) deyimiyle, gerçekten neler olup bittiğini göstermeyi ve geçmişteki insanların deneyimini mümkün olduğu kadar eksiksiz yakalamayı amaçlar.

Sözlü tarih görüşmeleri yapan tarihçi; geçmişe ait daha evvel hiçbir yazılı ya da görsel alana kaydedilmemiş, kaynağın az olduğu ya da hiç olmadığı yerlerde toplumların geçmişine ait sözlü kanıtların peşine düşer (Gökdemir, 2014, s. 200; Çakır, 2006, s. 57). Sözlü kanıtlar için yararlanılan kaynaklar, kişilerin iletişimsel belleği olabileceği gibi kişilerin tanık olmadığı ancak kuşaktan kuşağa aktarılmış olan kültürel belleği de olabilir. Sözlü tarih (Erdilek, 2006, s. 79), sessiz kalabalıkların tarihidir ve bu 
kalabalıkların seslerini duyurmalarına imkân sağlayan bir tarih araştırma metodudur. Alternatif bir bakış açısı getirir. Portelli (2005, s. 226), bu alternatif bakışla ulaşılan sözlü kaynakların insanların sadece ne yaptığını değil, aynı zamanda neyi yapamadıklarını da bizlere anlatır. Sözlü tarih Thompson'a göre (1999, s. 2-88), tarihin odak noktasını değiştirebilecek, yeni araştırma alanları açabilecek ve tarihi daha kapsamlı bir hale getirebilecek potansiyeli içinde barındırır. Danacıoğlu'nun belirttiği üzere sözlü tarihin amacı (2012, s. 136-138) sıradan hayatları ve sıradan öyküleri tarihe dâhil edebilmektir. Belli bir döneme ait kişisel deneyimleri, anıları, yaşantıları görüşmeler yoluyla belleğin derinliklerinden çıkarıp belli bir bağlamda yorumlayarak toplumların tarihinin inşasına katkıda bulunan bir araştırma yöntemidir. Lehane ve Goldman (1977, s. 174) sözlü tarihi, tarihsel bir önem taşıyan olaylara tanıklık etmiş sıradan insanların toplumsal belleğini korumak amacıyla yapılan sistematik görüşme yöntemi olarak tanımlar. Sözlü tarih Thompson'a göre de (2006, s. 23-25) disiplinlerarası bir yöntemdir. Öztürk (2010, s. 14) sözlü tarihin bir yandan yazılı kaynaklarda yer almayan bilgilere ulaşmanın fırsatını sunduğunu diğer taraftan yazılı kaynakları kendi çıkarları adına kurgulayanların ötesindeki bilgilere ulaşma potansiyelini barındırdığını vurgular.

Kyvıg ve Marty’e göre (2011, s. 72) yanıbaşımızdaki tarihle uğraşan tarihçilerin yaptığı, birinci elden bilgiye sahip kişilerden veriler elde etmek ve bu elde edilen verileri de toplam bilgiye eklemektir. Bu bağlamdan hareketle sözlü tarihle ilgili son derece önemli bir husus karşımıza çıkar. Sözlü tarih (Caunce, 2011, s. 12; Kyvıg ve Marty, 2011, s. 72-75) kendi başına bir amaç değil, amaca giden yolda bir araçtır. Tarihsel bilginin derlenmesi, sınıflandırılması, temalar oluşturulması ve nihayetinde çalışmanın ekseni bağlamında yorumlanması sürecinin yalnızca bir bölümüdür. Sözlü tarih çalışmasında öncelik (Balay ve Ocak, 2006, s. 264) tarihsel bir metnin ortaya çıkarılmasıdır. Bu bağlamda da Neyzi (2013, s. 10-11) sözlü tarihi, sözlü tarih anlatılarını ve bu anlatıların yorum sürecini içeren karma bir tür olarak nitelendirir.

Sözlü tarihle geniş insan kesimlerinin deneyimleri ve gündelik yaşamın farklı boyutları (ilyasoğlu, 2006, s. 18) belli bir tarihsellik içinde ele alınır ve böylece tarihin çeperi genişler. Sıradan insanlardan edinilen sözlü kanıt (Caunce, 2011, s.8) tarihin bütün olarak anlaşımasına olanak sağlar. Edinilen bu veriler tarihçilerin dayandıkları belgeleri tamamlayıcı ve alternatif bir tarih oluşturur. Böylece sözlü tarih, resmi tarihin yanında bir alternatif tarih (alternative history) olarak da işlev görür. Öztürk'ün belirttiği üzere (2013, s. 19-20) toplum yaşamının dinamiklerini anlamak için ne yukarıdan tarih anlayışı (top history) ne de alternatif ya da karşı tarih anlayışı tek başına yeterlidir. Çünkü toplumsal yaşam Öztürk'ün deyimiyle çelişkilidir, hareketlidir ve birtakım gerilimleri barındırır. Karşı tarih ya da alternatif tarih ise resmi tarihi dikkate almaz, sadece iletişimsel bellek üzerine anlatısını oluşturur. Sadece sözü merkeze alan yaklaşımların da sözü dışarıda bırakan yaklaşımlarda olduğu gibi sorunlu olduğu düşünülmektedir. Öztürk'ün ifadesiyle (2010, s. 16) bir sözlü tarih eseri yerine göre daha fazla tarih anlayışıyla yerine göre de alternatif tarih anlayışıyla tasarlanabilir. Günümüzde ise sözlü tarihten hareketle tarih anlatısı oluşturulurken, sözün dışında kalan kaynaklara da yönelinmekte böylece daha fazla tarih anlayışıyla olaylara ve döneme daha bütüncül bakılabilmektedir. 


\section{Bașkanın Adamları Filmindeki İmajlar ve Söylemler Üzerinden Tarih, Bellek ve İktidar Ilișkisine Bakmak}

\subsection{Filmin Künyesi}

$\begin{array}{ll}\text { Orijinal Ad } 1 & : \text { Wag the Dog } \\ \text { Yönetmen } & : \text { Barry Levinson } \\ \text { Senaryo } & \underline{\text { :Larry Beinhart, Hilary Henkin }} \\ \text { Süre } & : 97 \text { Dakika } \\ \text { Ülke } & : \text { Amerika Birleşik Devletleri } \\ \text { Oyuncular } & : \text { Dustin Hoffman, Robert De Niro, Anne } \\ & \text { Heche, Denis Leary, Willie Nelson } \\ \text { Tür } & : \text { Komedi, Politik, Dram } \\ \text { Vizyon Tarihi } & : 1998\end{array}$

\subsection{Filmin Hikâyesi}

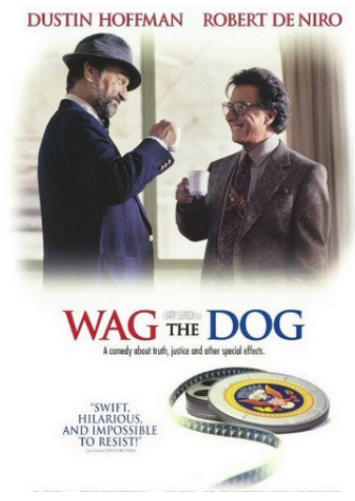

Amerika'da başkanlık seçimlerine az bir süre kala mevcut başkanın adı cinsel taciz olayına karışır. Beyaz Saray'ı ziyaret eden kızlardan biri, başkanın kendisine cinsel tacizde bulunduğunu iddia eder. Seçimin tekrar kazanılabilmesi için kriz, imaj, algı ve rıza yönetiminin yapılması ve halkın dikkatinin farklı bir yöne çevrilmesi gereklidir. Gerçeklerin ört bas edilmesi ve sahte gerçekliğin inşa edilerek halkın manipüle edilmesi amacıyla bu konuda uzman olan Conrad Brean görevlendirilir. Conrad Brean, halkın ve medyanın dikkatini dağıtmak amacıyla ABD ile pek işi olmadığı düşünülen Arnavutluk'la kurgusal bir savaş organize eder. Kurgusal savaşı daha gerçekgibi kılabilmek için bir Hollywood yapımcısı olan Stanley Motss'la anlaşır. Gerçekgibiliği inşa etmek ve manipülasyonu daha etkili kılabilmek için savaştan kaçan bir kadının ve ABD'li bir askerin Arnavutlar tarafından esir alındığını gösteren birtakım stüdyo çekimleri yapılır. Ayrıca senaryo gereği unutulmuş askere destek amacıyla sokaklardaki ağaçlara eski ayakkabılar asılır ve halkın duygularına seslenen kahramanlık şarkıları bestelenir. Sonuç olarak kurgusal bir savaş üzerinden yaratılan kahramanlık ve birlik algısı ile mevcut başkan, kamuoyu yoklamalarında önemli bir başarı kazanır.

\subsection{Film Çözümlemesi}

Politik (komedi unsurları da söz konusu) bir film olan Başkanın Adamları iktidarın içinde bulunduğu krize yönelik algı, imaj, itibar ve rıza yönetiminin nasıl yapıldığına dair önemli veriler sunar. Bir amaç doğrultusunda gündemin nasıl belirlendiği ve bu bağlamda rızanın2 nasıl üretildiği/imal edildiği filmsel imajlar ve söylemler üzerinden

2 Rızanın üretimi ya da rızanın İmalatı (Manufacturing Consent) en temelde medyanın bir yönlendirme aracı olarak kullanıldığı düşüncesine dayanır. Bu kavram ilk kez Walter Lippmann'ın Public Opinion (1997) kitabında kullanılmıştır. Lippman'a göre medya, kamuoyunun algısını imajlarla şekillendirmekte ve halkın dikkatini belirli bir yöne yönelterek gündemi belirlemektedir. Rızanın imalatı bağlamında öne çıkan diğer teorisyenler Noam 
ironik bir çerçevede gösterilir. Bu film anlatısında kriz yönetimi yapılırken ve hükümetin politikasına yönelik meşruiyet/rıza sağlanırken oryantalist temelli bir bakış açısı da devreye sokulur. Gündem belirleme3 sürecinde öteki nasıl inşa ve ilan edilir, ötekinin düşman olarak takdim edilebilmesi adına sahip olması gereken birtakım kodlar neler olmalıdır gibi sorulara da bu film, anlatı boyunca ironik bir biçimde cevap verir. Film, medya ve iktidar ilişkisini eleştirel bir bakış açısıyla izleyiciye takdim ediyormuş gibi gözükse de burada ası üzerinde durulması gereken nokta belirli ideolojiler bağlamında inşa edilen resmi tarih yazımıdır.

Filmin konusu ABD Başkanı'nın karıştığı cinsel içerikli bir krize ve bu krizi yönetmek adına medya eliyle üretilen sahte/yapay savaşa ve devamında yaşananlara dayanır. Amerika Devlet Başkanlığı seçimlerine çok az kalmıştır; fakat hâlihazırdaki Başkan'ın ismi bir taciz skandalına karışır. Seçimden evvel başkanlık koltuğunun gitmesine neden olabilecek bu krizi yönetmek adına Beyaz Saray danışmanlarından Conrad Brean görevlendirilir. Brean, bu krizi aşabilmek ve kitlelerin algısını Başkan'ın lehine yönetebilmek adına Arnavutluk'la kurgusal/sahte bir savaş çıkarır. Başkan'ın itibarını ve imajını tekrar eski haline getirebilmek ve kitlelerin rızasını tekrar kazanabilmek için bu savaşın gerçekgibilik ilkesine göre tasarlanması gerekmektedir. Bu eksende Brean, Hollywood'un en iyi yapımcılarından Stanley Motss ile anlaşma yapar. Böylece sahte savaş, birtakım sinematik görsel düzenlemelerle gerçek bir savaşa dönüşebilecektir. Görsel inandırıcılık dışında içerik de Amerikan halkını bu savaşın gerçekliğine inandırmalıdır. Manipülasyonu kuvvetlendirmek ve kitlelerin ilgisini istenilen yöne çekmek adına birtakım unsurlardan yararlanılır: savaşta kucağında kedisiyle kaçan Arnavut bir kadın, Arnavutlar tarafından esir alınan ABD’li bir asker, esir düşen askere dair üretilen imajlar, kitlelerin desteğini sağlamak adına ayakkabı/pabuç gibi ikonik birtakım unsurların kullanımının özendirilmesi, eski bir papuç olarak nitelendirilen askerle ilgili üretilen bir şarkı. Krizi yönetmek adına başvurulan tüm bu taktik ve stratejiler amacına ulaşır. Kriz başarılı bir şekilde yönetilir, kitlelerin algısı Başkan'ın lehine yönlendirilerek Başkan'ın iktidarına yönelik rızanın üretimi de sağlanmış olur.

Anlatının en başından sonuna kadar krizi yönetmek adına atılan tüm adımlar, "kurgusal bir resmi tarihi” inşa eder. Esasında ilk kesitler itibariyle söylenecek olursa kurgusal resmi tarih, iletişimsel ve kültürel belleğin şekillendirilmesiyle yazılmaya başlar. İletişimsel ve kültürel bellek, hâlihazırdaki Amerikan hükümetinin tahakkümü altında

Chomsky ve Edward Herman Rızanın Imalatı, Kitle Medyasının Ekonomi Politiği (2012) adlı eserlerinde medyanın iktidar, sermaye ve güç ile olan ilişkisine odaklanır. Düşünürlere göre medya iktidara, sermayeye ve güce hizmet eden bir araçtır. Medya, siyasal iktidarların fikir ve düşüncelerini kitlelere yani kamuoyuna aktaran ve istenilen rızanın üretilmesi noktasında önemli bir role sahip bir fail konumundadır.

3 Kitle iletişim araçlarının etkisini anlamak bağlamında çeşitli kuramlar geliştirildi. M. McCombs ve D. Shaw'ın (1995) gündem belirleme (Agenda Settings) adını verdikleri kuramları da medya ve etkilerine odaklanan kuramlardan biridir. Bu kurama göre halkın çeşitli olayların ve konuların önemlerini algılayışlarının altında (Mutlu, 2004, s. 119) kitle iletişim araçlarının olayları ve konuları ele alış biçimleri yatar. Bu yaklaşım kitle iletişim araçlarının belirli bağlamlar altında belirli konuları seçtiğini ve kitlelere sunduğunu, bu seçimin de kitlelerin düşündüğü ve konuştuğu konuları belirlediğini ileri sürer. Kitle iletişim araçları ile toplum birtakım sahte gündemlerle meşgul edilebilir (Güngör, 2013, s. 113), özellikle siyasal iktidarlar bu süreçte başat bir rol oynar. Bu yaklaşıma göre kitle iletişim araçları izleyici kitlelerin ilgisini belirli bir yöne çekebilir. Eğer izleyici kitle o konuya yeterince ilgi gösterirse toplum içinde o konuyla ilgili birtakım kanaatler ortaya çıkabilir. Nihayetinde ise ilgili sunumla ilgili bir kamuoyu ortaya çıkar. 
biçimlenir ve sahte bir gerçeklikle yeniden tasarlanır. Film anlatısındaki resmi tarihin inşasında ayrıca nesneler belleğinden de sıklıkla yararlanılır; çünkü nesneler belleği, yeni bir gerçekliğin inşası ve bu inşanın kabulü noktasında önemli bir potansiyele sahiptir. Tüm bu unsurları ve ilişkileri görmek adına filmi kesit kesit/kare kare ele almak gerekmektedir.

Kurgusal resmi tarihin inşasıyla ilgili Beyaz Saray danışmanlarından Brean'ın attığı ilk adım Başkan'ın Çin ziyaretini bir gün daha geciktirmesi yönünde olur. Başkanın hasta olduğu yalanı basın bürosu çalışanları tarafından bir bültenle açıklanmalıdır. Brean, bunu zaman kazanmak için yapar. Bu konuşmanın ardından kurgusal gerçeklikle ilgili inşasına devam eder. Başkanın Çin'e gitme nedeni hakkında B3 bombardıman uçağı (hâlihazırda envanterde böyle bir uçak yoktur) ile ilgili bir dedikodu yayılmasını ister. Ona göre bir haberin doğru olması gerekmez, amaç seçime kadar seçmenin dikkatini başka bir yöne çevirmektir. Kesit değişir. Brean ve bu süreçte Brean'ın asistanı konumundaki Winifred Ames uçakla Los Angeles'a Hollywood yapımcısını görmeye gider.

Brean, uçak yolculuğu sırasında Winifred'e "bu konuda endişelenme, yeni bir şey değif' diyerek kurgusal bir gerçeklik üzerinden inşa ettikleri resmi tarihi hem örnekler hem de meşrulaştırmaya çalışır. "Reagan hükümeti döneminde Beyrut'ta 240 denizci öldürüldü. 24 saat sonra Grenada'yı istila ettik. Bu onların işiydi. Hikâyeyi değiştir, başrolü değiştir. Yeni bir kavram değil". Brean ve Winifred arasındaki diyalog, resmi tarihin daha evvel defalarca sahte bir gerçeklikle yazıldığını örnekler niteliktedir.

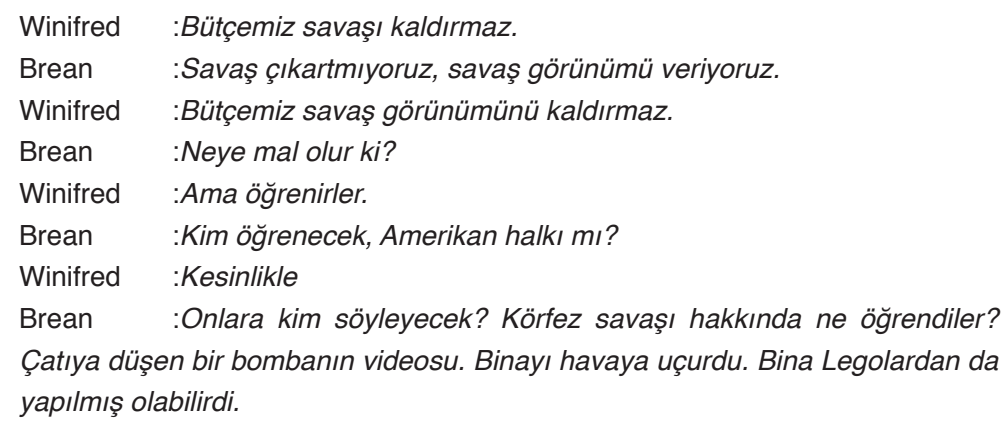

Kesit değişir. Kriz yönetimi sürecinde kiminle kurgusal bir savaş çıkartılacağı değişen kesitle dile getirilir: "Arnavutluk". Winifred, Brean'a neden Arnavutluk sorusunu sorar. Brean ise "neden olmasın, onlar hakkında ne biliyorsun?" sorusunu yöneltir. Hiçbir şey cevabını alan Brean, Arnavutların güvenilmez ve itici göründüklerini söyler. Ona göre Arnavutluk'u kim tanır ve Arnavutlara kim güvenir? Bu taktik ve stratejiden sonra basın toplantısında Arnavutluk'taki durumun Müslüman kökten dinci anti-Amerikan ayaklanmasıyla bir ilişkisi var mı sorusu sorulur. Bu soruyla Arnavutluk, kökten dinci ve Amerikan karşıtı bir terör devleti olarak Amerikan halkına sunulmaya/taktim edilmeye başlar. 
$\mathrm{Bu}$ söylemler oryantalist bakış açısının yine devrede olduğunun göstergesidir. Oryantalizm, en basit ifadeyle biz-onlar düalizmi üzerinde temellenir. Said'in Orientalism/ Şarkiyatçılık adlı eserinde (1978; 2008) oryantalizm, Batı ile Doğu arasındaki epistemolojik ve ontolojik bir ayrım üzerine kurulu bir düşünce şekli olarak ifade edilir. Kontny'nin ifadesiyle (2002, s. 117) Batı (occident) düşüncesine sahip bir kişinin (Oryantalist), Doğu (Orient) olarak ifade ettiği ve kendi dışındaki birtakım özelliklerle kodladığı siyasal ve kültürel bir oluşum hakkındaki söylemleridir. Oryantalistlerin tasavvurlarındaki Doğu imgesi inşa edilmiş bir gerçekliktir. Batı kendi endişelerini ve kaygılarını hayali bir Doğu imgesi üzerinden somutlaştırır. Batı, birtakım kodlar üzerinden ötekini yaratır; bu düşüncenin amacı sömürgeci bir eylemi kolaylaştırmak ve uygulayabilmektir. Batı'nın Doğu hakkındaki başat düşünce biçimi ve algısı olarak ifade edilebilecek bu düşünce sisteminde Batı, Doğu üzerinde bir hâkimiyet ve otorite kurabilmek amacındadır. Batı kendi ürettiği bilgi üzerinden Doğuyu öteki olarak takdim eder ve böylece birtakım emperyalist idealler kolayca gerçekleşebilir. Bu bakış açısı, kurgusal resmi tarihin de inşa sürecini belirler. Resmi tarih yazımı, daha evvel belirtildiği üzere iletişimsel ve kültürel bellekten ve ayrıca nesneler belleğinden bağımsız bir minvalde gelişmez. Bu bağlamda anlatı içindeki birtakım suni gündemler ve uydurma olaylar (psudo events), doğrudan belleği (bellek türlerini) şekillendiren unsurlar olarak anlatıda karşımıza çıkar. Bu unsurlar Brean ve Winifred'in Hollywood yapımcısı Stanley Motss'u ziyaretiyle somutlanmaya başlar. Bellek üzerine ortaya konulan kavramlar, bir film yapımcısı tarafından inşa edilecektir.

Motss, Brean'a "ben gösteri dünyasındayım değil mi bana neden geldiniz” sorusunu yöneltir. Bunun üzerine Brean, neden olduğunu anlatmaya başlar ve aralarında şu diyolog geçer:

\author{
Brean $\quad: 54,40$ ya da savaş. Bu ne anlama geliyor? \\ Motss :Bu bir slogan. \\ Brean :Sloganları hatırlıyoruz, kahrolası savaşları hatırlamıyoruz bile. \\ Nedeni ne biliyor muyuz? Sebebi gösteri dünyası. \\ Motss :Anliyorum. \\ Brean :Napalmla kaplanmış çıplak kız. Zafer için $V$ işareti. Surabachi \\ Dağı'nda bayrak diken 5 denizci. Görüntüyü 50 yıl hatırlarsın ama savaşı \\ unutursun. Savaş gösteri dünyasıdır. Biz bu yüzden buradayız.
}

Brean ve Motss arasındaki konuşma devam ederken, Brean'ın bahsettiği önemli olaylara dair fotoğraflar ekrana yansır. Daha evvel söylendiği üzere resmi tarihin inşasında nesneler belleği önemli bir eyleyen olarak işlev görür. Yıllar sonra o ana dair anıları fotoğrafla, kullanılmış herhangi bir nesneyle ya da kokuyla tekrar canlandıran nesneler belleği, kurgusal resmi tarihi kurgusallıktan çıkarmada önemli bir rol oynar. Bu filmsel anlatıda da nesneler belleğinin resmi tarih yazımındaki işlevi fotoğraflar üzerinden açıkça gösterilir. Belleği harekete geçiren bu fotoğrafların izleyiciye gösterilmesiyle izleyici gerçeklikle yanılsama arasında düşünsel bir katılıma ve bir sorgulamaya davet edilir. 


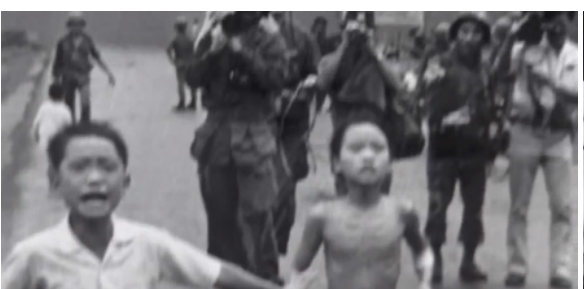

Görsel 1. Napalmla kaplanmış çıplak kız

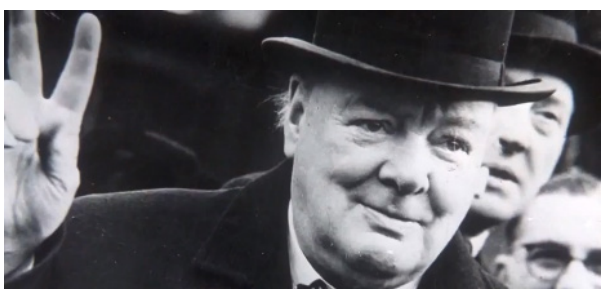

Görsel 2. Zafer için V işareti

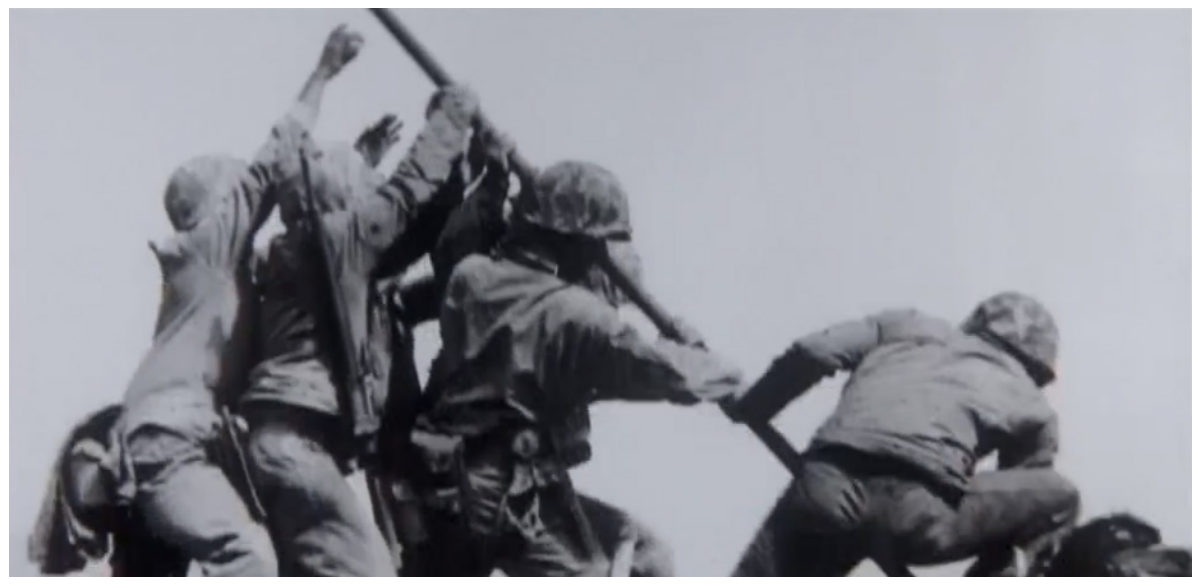

Görsel 3. Surabachi Dağı'nda Bayrak Diken 5 Denizci

Sahne değişir. Neden Arnavutluk sorusunu bu kez Motss, Brean'a sorar. Brean'ın Arnavutluk'la ilgili Winifred'e yapmış olduğu açıklamanın bir benzerini Motss'a yapmış olduğu sahnenin değişmesiyle anlaşılır. Eksiltili anlatım söz konusudur. Motss, Brean'a "bir noktada öğrenmek zorundalar" cevabını verir. Brean, "kimler" diyerek inşa edilen resmi tarihi yine örneklemeye başlar: "Kennedy'i kim öldürdü? Warren Raporu'nun ilk müsveddesini okudum. Sarhoş bir şoför tarafından öldürüldü yazıyordu. Körfez Savaşı'nı izledin. Günlerce ne gördün? Çatıya düşen bir akıllı bomba. Gerçek? 0 çekimi yaptığımızda ben binadaydım. Onu Virginia'da Çağlayan Kilisesi'nde bir stüdyoda çektik. Bir binanın onda biri büyüklüğünde maketti”. Motss, bunun üzerine Brean'a "doğru mu bu" sorusunu sorar. Brean "nereden bilelim yahu" diyerek kriz yönetimi adına neler yapılabileceğinin ipuçlarını hem Motss'a hem de izleyiciye verir. Esasında Brean, Amerikan resmi tarihiyle ilgili söylediklerinin tam olarak kurgusal bir gerçeklik olup olmadığını açıkça belirtmez. Fakat kriz yönetim süreciyle resmi tarih arasındaki ilişkiyi açıkça gözler önüne serer. Bu bağlamda o döneme tanıklık etmiş olan insanların iletişimsel ve nesneler belleklerinin de iktidarın ideolojisi ekseninde nasıl şekillenebilir ve değiştirilebilir bir şey olduğunun da altını çizer.

Bu sahne itibariyle kurgusal resmi tarih yazımının detayları konuşulmaya başlar. Brean ve Motss, bir savaş üretecektir. Esasında bu savaş değil, bir gösteri üretimidir. Bu 
nedenle gösteri toplumuna dair tüm eyleyenler devreye girmelidir. Brean'ın deyişiyle konuya, şarkıya, bazı görsel ögelere intiyaç vardır. Oryantalist söylem bir kez daha bu kesit itibariyle devreye girer (Oryantalist söyleme bir eleştiri getiriyormuş gibi gözükse de yine de bu ötekileştirici söylem dolaşıma sokulur). Motss'un deyişiyle Arnavutlar, "Birleşik Devletler'deki dinsiz iblisi, bizim hayat tarzımızı (Amerikan rüyasını) yok etmek istiyorlar. Başkan Çin'de. B-3 bombardıman uçağının Arnavutluk'a sevki konusuyla ilgileniyor. Ellerinde bomba olduğunun farkına vardık. Hayır, hayır bomba orada değil. Çünkü rokete filan sahip olmaları gerekirdi. Onlar bir yığın ecnebi. Bir bombalı çanta. Füzelere ihtiyacın yok. Bombayı çantaya koyabilirsin. Arnavut teröristler, Amerika'ya bombayı sokma girişimi nedeniyle Kanada'ya bir bombalı çanta yerleştirmişlerdir. Bu üretimdir, durum bu. Birinci perde Arnavutluk her şeyi inkâr eder. Başkan yayına çıkar. Sakin olun". Motss, üretimine ikinci perde diyerek devam eder; ama Brean, Motss'un sözlerini "ikinci perdeye ihtiyacımız yok, seçimlere kadar 11 günlüğüne ilgilerini çekmeliyiz sadece" diyerek yarıda keser.

$\mathrm{Bu}$ kesit itibariyle kamuoyunu sahte bir savaşa inandırabilmek adına iletişimsel, nesneler ve kültürel belleğin inşasına başlanır. Bu sahte resmi tarihin/tarihyazımının inşasında geleneksel medya oldukça önem taşır. Kitlelerin algısının farklı bir yöne doğru yönlendirme ediminde New York Times ve Washington Post gibi gazeteler önemli bir rol oynar ve savaşı ilk sayfalarına taşır. Arnavutluk Cumhuriyeti'yle bir savaşın başlayacağına dair bir haber radyodan duyulur: Bu son dakika haberini Air Force One'dan henüz edindik. Birleşik Devletler Başkanı gizlilik ihtiyacından dolayı özür dilediğini ve bunun savaşta yer alanlar adına gerekli olduğunun garantisini verdiğini söyledi. Arnavutluk Cumhuriyeti'nin dünya çapında terörizm için zemin hazırlama arzusunda olduğunu ifade etti. Birleşik Devletler ile Arnavutluk Cumhuriyeti arasında bir savaş halinin başlayacak ya da başlamak üzere olduğundan söz etti.

Gazetenin ve radyonun yanı sıra televizyon da bellek üretiminde devreye sokulur. Hollywood yapımcısına göre kitleleri ikna ve manipüle edebilecek imajlar/haber filmi üretilmelidir. Bu bağlamda Arnavut teröristler tarafından evinden çıkarılan moloz içindeki genç bir kız imajı tasarlanır. Bu Arnavut genç kız (bu rolü oynayacak olan Amerikalı kadın, katalogdaki fotoğraflar içinden seçilir) hikâyeye göre Arnavut teröristlerin elinden kaçar, bu nedenle Motss'un deyişiyle korumaya seferber olunan kişi ilk etapta Arnavut kız olacaktır. Genç kıza dair imaj, kitlelerin algısını daha etkili bir şekilde yönetebilmek ve rızayı üretebilmek/ima edebilmek adına daha detaylı bir şekilde mavi ekranlı stüdyoda tasarlanmaya başlanır. Bu üretilmiş sahte gerçeklik artık gerçek olarak algılanan resmi tarihe eklemlenir ve son dakika haberi olarak ekranlara yansır: Arnavutluk cephesinden bir son dakika özel haberi. Az önce edindiğimiz bilgiye göre bu görüntülerde genç Arnavut vatandaşı, köyündeki teröristlerden kaçmaya çalışıyor. 

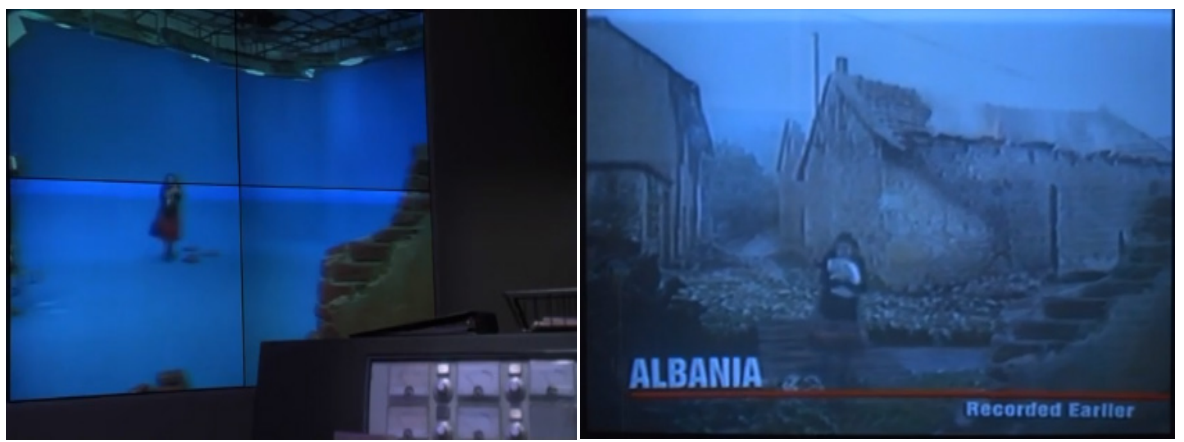

Görsel 4-5. Arnavut genç kızın sahte savaş görüntüsü/kurgulanmış imajı, stüdyo ortamında tasarlanır. Gerçekgibiliği arttırmak ve kitlelerin algısını ve rızasını daha etkili bir şekilde yönetmek için üretilmiş hareketli imaja alev, çığlık, siren sesi, yanan bir köprü ve beyaz bir kedi gibi unsurlar eklenir. Üretilen bu yapıntı imajın kitlelerin algılarında gerçeğe dönüşebilmesi ise ana haber bültenlerinde gösterilmesi ile mümkün olur.

Krizi en etkili bir şekilde yönetebilmek ve kitlelerin ilgisini ve rızasını arzu edilen istikamete yönlendirebilmek için resmi tarihin ve kişisel belleğin inşasına yönelik edimler sahneler ve sekanslar ilerledikçe devam eder. Savaştan kaçan Arnavut kadına yönelik uydurma olaylar (psudo events) detaylandırılır. Brean ve asistanı konumundaki Winifred arasındaki diyalog bu durumu örnekler:

$\begin{array}{ll}\text { Brean } & \text { :ihtiyar kurt ne zaman iniyor? (Başkan kastedilir) } \\ \text { Winifred } & \text { :Yarın sabah saat 5'te. } \\ \text { Brean } & \text { :Havaalanında herhangi bir şey var mı? } \\ \text { Winifred } & \text { :Basına göre yok, sen ne düşünüyorsun? } \\ \text { Brean } & \text { :Benim düşündüğ̈̈m şu. Yağmur yağacak mı? }\end{array}$

Brean'ın bu sorusu üzerine Winifred, havaalanındaki hava durumunu öğrenmek için telefon görüşmesi yapar. Başkanın ineceği Andrews'te yağmur olmadığı, Boca Raton'da ise yağmur yağacağı bilgisi gelir. Aşağıdaki diyalog üzerine Başkanın uçağı Boca'ya yöneltilir.

Brean : Acaba bir bayram var mı, bir hasat bayramı? Arnavut hasat bayramı, onun gibi bir şey?

Winifred, bu soru üzerine telefonda görüştüğü kişiiye "bana bir hasat bayramı bul, Arnavut hasat bayramı" der.

Brean :Her neyse bunun ilk demeti, son demeti... Kutsal geleneksel bir sunum olduğunu söyleyerek kutsal şey neyse onu Başkan'a verir.

Winifred :Bunu Arnavutça mı söylüyor?

Brean : :Arnavutça konuşuyor. Çünkü kutsal, ermiş, ihtiyar annesinin anlayabileceği tek yol bu. Şimdi yaşıı bayan konuşmaya başlar. Barışı sadece buraya getirmekle kalmadınız. 
Hayır hayır çocuk konuşur. Masumiyetin yüzü, kötümserlik yok. Şimdi yaşlı kadın dayanamaz ve ağlamaya başlar. Ihtiyar kurt korumalarından sıyrıır, oraya gider. Kendi paltosuyla kadını örter, hikâyenin sonu.
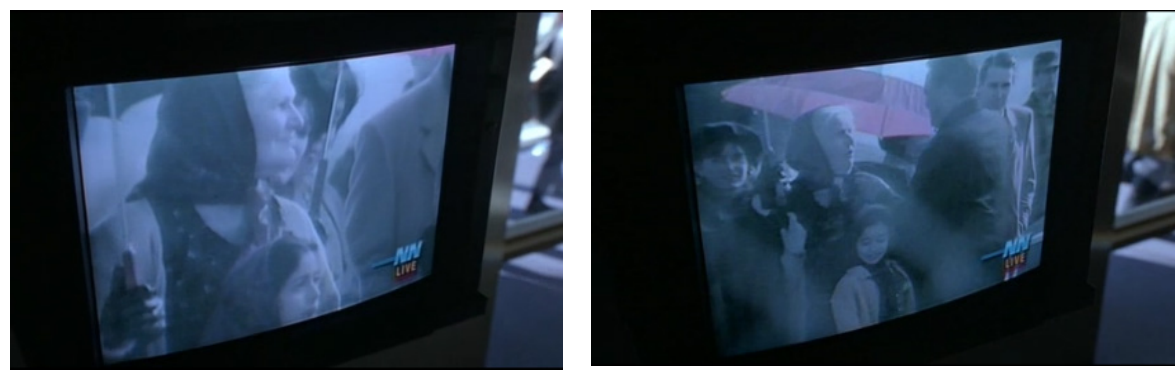

Görsel 6-7. Bu film anlatısında televizyon, inşa edilmiş gerçekliği/gerçekgibiliği artıran bir araç olarak sıklıkla tercih edilir. Brean'ın kurguladığı sahte olaylar, havaalanında sahnelenir. $\mathrm{Bu}$ sahneleme televizyonda ana haber bültenlerinde izleyiciye sunulur. Bu kesitte sinema göstergebilimi ekseninde gösteren ve gösterilen ilişkisinden bahsetmek mümkündür. Hem şemsiye hem de palto bu sahnede bir göstergeye dönüşür. Arnavut yaşlı kadın ve küçük Arnavut kız, kendilerine tutulan bir şemsiyenin altındadır. Ayrıca Amerikan Başkanı, kendi paltosunu çıkarır ve yaşı kadına kendi elleriyle giydirir. Temel anlamda sadece kendi işlevlerine sahip olan bu iki nesne, yan anlamsal düzeyde Amerika'nın koruyuculuğuna bir göndermede bulunur. Gösterilen düzeyinde yorumlandığında mevcut iki göstergeden Amerika'nın sadece terörist unsurlarla mücadele ettiği, kadınları ve çocukları yani sivil masum halkı koruduğu gibi bir anlam çıkarmak mümkündür.

Halkı manipüle etmek ve arzu edilen tarafa doğru halkın ilgisini çekebilmek adına bir şarkı bestelenir. Kurgusal savaşa ve sahte gerçeklere dair üretilen tüm eyleyenler şarkının sözlerine dâhil edilir.

"Şimdi rüyalarını koruma zamanıdır. Amerikan sınırlarımızı koruyoruz. Amerikan rüyasını koruyoruz. Demokrasi için savaşma ve ülkemizi hür tutma hakkımızı koruyoruz. Amerikan ruhumuzu koruyoruz. Özgürlük kayalığı üzerine ülkemiz kuruldu. Bizlerse insan olarak hür tutmak zorundayız onu. Hayat için, özgürlük için, mutluluk aramak için senin bağımsızlığın için Amerikan sınırlarımızı koruyoruz. Amerikan rüyasını koruyoruz ".

İlerleyen kesitlerde CIA'in uydurma olayları öğrendiği ve kurgulanmış savaşı bitirdiği görülür. Sahte savaşın bitirildiği haberi, yine televizyonun gücünden yararlanılarak gerçek kılınır. Bu andan itibaren eğer kriz etkili bir şekilde yönetilmek ve arzu edilen rıza sağlanmak isteniyorsa yeni bir gerçeklik, yeni bir resmi tarih yazımı devreye sokulmalıdır. İletişimsel ve kültürel bellek yeni unsurlarla yeniden tasarlanmalı, nesneler belleğini harekete geçirecek olan yeni imgeler sahte gerçekliğe dâhil edilmelidir. Bu bağlamda Hollywood yapımcısı Motss'un deyişiyle ikinci perde başlamalı ve bir kahraman imgesi üretilmelidir. Motss'a göre bir kahraman olmadan bir savaş olmaz, bu çerçevede cesur bir Amerikan askeri arkada bırakılmış gibi gösterilmelidir. Bu noktada eski bir ayakkabı/ pabuç ile arkada bırakılmış Amerikan askeri arasında göstergesel bir ilişki kurulur. Pabuç bir göstergeye dönüşür. Gösteren kullanılmayan herhangi eski bir ayakkabı, 
gösterilen ise kurgulanmış sahte savaşta arkada unutulan Amerikan askeri. Nedensiz bir bağlamda kurulan bu ilişki ile kitlenin dikkati seçimlere kadar dağıtılmaya ve üretilen kahraman imgesi aracıığıyla mevcut Başkan'ın tekrar seçilmesi sağlanmaya çalışılır. $\mathrm{Bu}$ kesit itibariyle sahte kahraman imgesi tasarlanmaya başlanır. Uydurma olaylara göre Başkan, sahte kahraman Schumann'ın düşman saflarında yakalandığına yönelik duygulara seslenen bir konuşma yapar. Er Ryan'ı Kurtarmak (1998) gibi filmlerden aşina olunduğu gibi yeni gerçeklikte cephe gerisindeki bir asker, ülkesine sağ salim geri getirilmelidir. Böylece mevcut hükümetin yeni arzu nesnesi de ortaya çıkar.

"Sevgili vatandaşlarım. Tanrıya şükürler olsun. Barış artık çok yakınımızdadır. Nükleer terörizm tehlikesi atlatılmıştır. Arnavutluk Başbakanı ile temas halindeyiz. Kendisi bana güvence verdi ve Arnavutluk hükümeti de ülkemiz aleyhine herhangi bir çalışmaları olmadıklarını teyit etti. 303 numaralı birimden bir askerimiz düşman hatlarının gerisinde kalmıştır. Kayıp askerimizin ailesine sesleniyorum. Bu kahraman askerimizi bulup derhal evine getirmek için hiçbir çabadan kaçınılmayacaktır. Schumann'ı tutsak olarak gösteren bu fotoğraf elimize yeni geçti. Schumann bir grup muhalif Arnavut teröristin elinde. Mors alfabesini ne kadar biliyorsunuz bilmiyorum ama kamerayı buraya yaklaştırabilir misiniz ıütfen. Gördügünüz gibi kazağı yırtılmış. Yer yer delinmiş olan kazağında çizgiler ve noktalar var ve bu çizgiler ve noktalar mors alfabesi ile bir mesaj veriyor. Bu mesaj ise, cesaret anne. Bana verilen bilgiye göre silah arkadaşları ona eski pabuç lakabı takmışlar. Sevgili vatandaşlarım, eski pabucumuzu bulmak için hiçbir çabadan kaçınmayacağız".

Bu konuşma daha önceki sahnelerde olduğu gibi yine televizyon ekranlarından geniş kitlelere aktarılır. Ele alınan film anlatısında gerçeklik/hakikat algısı ile televizyon arasında sıklıkla bir ilişki kurulur. Filmin konumlanma noktasından ve söyleminden hareketle televizyon üzerinden kurulan gerçeklik inşasına yönelik bir eleştiriden söz etmek mümkündür.

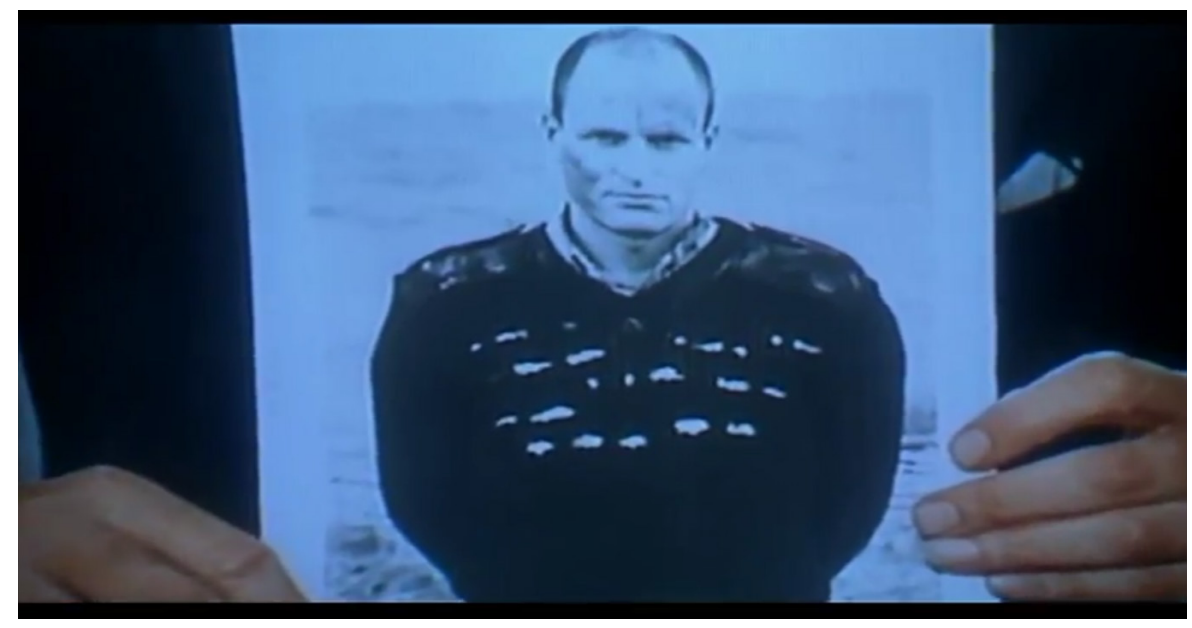


Görsel 8. Krizi ve algıyı yönetmek için kurgulanmış savaşta sahte bir kahraman imgesi üretilir. Cephe gerisinde kalan ve Başkan tarafından kurtarılacağı ifade edilen Schumann, nesneler belleğinin bir parçası haline getirilir. İnşa edilen kahraman askere yönelik sahnelenmiş yapay bir fotoğraf, iletişimsel ve nesneler belleğine dâhil edilir. Kurgulanmış resmi tarih, kitlelerin kişisel/ iletişimsel belleğini yönetebilmek için fotoğraf gibi nesnelerin gücünden ve potansiyelinden yararlanmayı seçer. Böylece belirli bir zaman sonra nesneler belleğine dâhil olan bu fotoğrafla üretilmiş olan gerçeklik, bir hakikat olarak algılanacak ve hatırlanacaktır. $O$ ana dair hakikati ortaya çıkarabilecek eyleyenlerden biri sözlü tarih olabilir. Sözlü tarih, var olan ana yönelik hakikatle bağını kaybetmemiş iletişimsel belleği alternatif ya da karşıt tarih ekseninde keşfetme potansiyelini içinde barındırabilir.

Bu minvalde kurgusal savaşa ve sahte gerçeklere dair yeni bir şarkı daha bestelenir. "Eski Güzel Ayakkabı" (Good Old Shoe) adı verilen bu kahramanlık bestesi, kültürel belleğe dâhil edilir. Gerçekliğin inşasında ve belleğin manipüle edilmesinde kültürel belleğin biçimlendirilmesi oldukça önem taşır. Şarkı, eski bir etiketle basılarak plak formunda Meclis Kütüphanesi Halk Müziği Bölümü’ne (1930) eklenir. Böylece sanki eski tarihlerde basıımış etkisi uyandırılmaya çalışıır. Mevcut iktidar, kurgulanmış resmi tarihini kültürel/toplumsal belleği de yeniden inşa ederek daha gerçekçi kılmaya çalışır. Kahramanlık imgesi olan asker Schumann'a, savaş sloganı "Cesaret Anne"ye (Courage Mom) ve "Eski Güzel Ayakkabı" adlı kahramanlık bestesine ek olarak, gösteri toplumunun bir gereği olarak var olan durumun etkisinin arttırılması amacıyla simgeselleştirme ediminden de yararlanılır. Yani cephe gerisinde kurtarılmayı bekleyen kahraman asker Schumann olayı simgeselleştirilir. Brean ve Motss eski pabuçları ağaçlara, tellere ve telefon direklerine asar. Bu simgesel edim, geniş kitleler tarafından benimsenir ve birçok yerde edimselleşir. Ağaçlara ya da direklere asılan eski pabuçlar, temel anlamının dışında yan anlamsal düzeyde farklı bir anlam taşımaya başlar. Pabuç göstergesi "Cesaret Anne" sloganı gereği cephe gerisindeki kahraman asker Schumann'ın kurtarılmasına, vatanseverliğe ve mevcut Başkan'ın önderliğinde Amerikan halkının birlik ve beraberliğine bir göndermede bulunur.
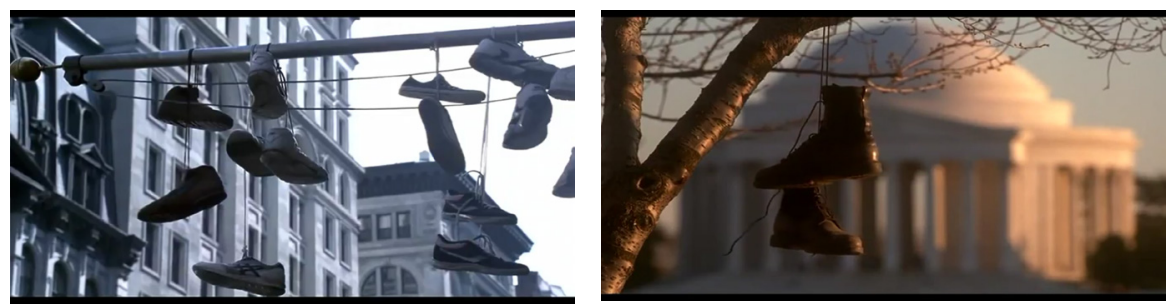

Görsel 9-10. Kurgulanmış kahraman imgesi, aynı zamanda simgeselleştirilir. Eski pabuçlarla, cephe gerisinde kurtarılmayı bekleyen Schumann arasında nedensiz (gösteren ve gösterilen arasında ilişki) bir ilişki kurulur. Eski pabuç fırlatma, geniş kitleler tarafından benimsenerek sosyal bir kampanyaya dönüştürülür. İnsanlar ayrıca destek amacıyla eski pabuç imgeleri taşıyan ve Arnavutluk'a hakaret içeren kıyafetler giymeye başlar. Seçime sekiz gün kala kitlelerin ilgisi arzu edilen tarafa doğru iyice yönlendirilir. Böylece kitlelerin destek oranı, mevcut Başkan'ın lehine doğru artmaya başlar. 
İlerleyen kesitlerde sahte kahraman Schumann, yapay gündem çerçevesinde cephe gerisinden kurtarılmış gibi yapılarak Amerika topraklarına getirilmek istenir. Böylece seçime birkaç gün kala Başkan'a olan destek oranı daha da artacaktır. Bu kurtarma operasyonu, bir gösteriye (gösteri toplumu) dönüştürülmelidir. Bunun için Andrews Hava Üssü’nde Evine Hoş geldin Eski Pabuç pankartlarıyla bir tören düzenlenir. Bu karşılama töreni geleneksel medyada haber bültenlerinde geniş kitlelere aktarılır. Fakat ilerleyen sahnelerde Schumann'ın son on iki yılını askeri bir cezaevinde geçirmiş bir mahkûm olduğu anlaşılır. Kurgulanmış savaşın sahte kahramanı on iki yıldır hapishanededir, suçu ise bir rahibeye tecavüz etmektir. Halen yürürlükte olan cezasının yanı sıra aynı zamanda psikolojik birtakım sorunları da vardır, saldırganlaşmaması için ilaçlara da mahkûmdur. Schumann'a yönelik karakter tasarımında ortaya konulan bu verileri, sinema dilinde sıklıkla kullanılan bir "ekme" olarak yorumlamak mümkündür. Ana akım sinemada ekilen yani anlatının henüz başında ya da ortasında gösterilen herhangi bir şey anlatının devamında "biçilecektir" yani kullanılacaktır. İlerleyen sahnelerde bu popüler sinemasal dil, edimselleşir. Hava koşulları nedeniyle Schumann'ı taşıyan uçak kırsal alana düşer. Schumann'la birlikte uçakta kriz kampanyasını yürüten Brean, Motss ve Winifred de vardır. Kaza sonucu kimse yaralanmaz ve bir çiftçinin yardımıyla tüm eyleyenler küçük bir markete kadar gitmeyi başarır. Krizi ve algıyı nasıl yöneteceklerini tartışan Brean, Motss ve Winifred'in tartışmalarını fırsat bilen Schumann market sahibinin kızını gözüne kestirir. Aldığı ilaçların etkisiyle saldırgan ve aklı uyuşuk olan sahte kahraman, market sahibinin kızını evine kadar takip eder. Market sahibi, kızının çığlıklarını duyar, bir tüfekle hızla eve koşar ve Schumann'ı vurur.

Eski Pabuç'un öldürülmesiyle yeni bir kriz ortaya çıkar; ama bu durum Motss'un şu sözleriyle etkili bir şekilde yönetilir ve çözülür: "Ve bir savaş kahramanının zaferle dönüşünden daha mükemmel ne olabilir". Bu söylemin ardından askeri bando sesi ve bir marş, sesçil evreni doldurur. Kurgulanmış savaşın ölen sahte kahramanı Schumann için askeri bir tören düzenlenir. Tüm politikacılar ve basın törendedir. İnşa edilmiş kahramanlık imgesinin cenaze töreni de gösteri toplumunun bir parçası haline getirilir. Televizyon, inşa edilmiş bu resmi tarihi ve iletişimsel belleği gerçekçi kılmak için daha evvel olduğu gibi yine devreye sokulur. 

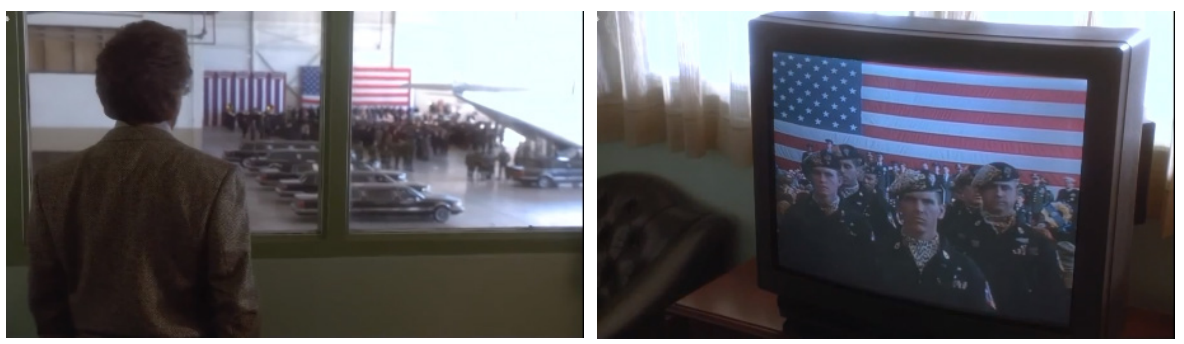

Görsel 10-11. Anlatı boyunca gerçeklerin ört bas edilmesi sürecinde üretilen sahte gerçeklerden biri de düzenlenen askeri cenaze meresimidir. Krizi ve rızayı yönetmek amacıyla kurgulanmış resmi tarih yazımı bando ve marş, bayrak, askeri geçit töreni, politikacılar, basın ve ayrıca tüm sürecin kitlelere aktarıldığı televizyon aracılığı ile gerçek kılınmaya çalışılır.

Anlatı boyunca Brean ve Motss tarafından yönetilen kriz ve algı yönetimi sonuçlarını verir. Kitlelerin mevcut Başkan'a olan desteği \%89'a ulaşır. Motss'a göre inşa edilen resmi tarihin, herhangi bir Hollywood yapımından farkı yoktur. Brean ve Motss yorgunluk kahvelerini içer; artık işleri başarıyla sona ermiştir. Ama televizyondan gelen sesler esenlikli durumu tekrar kırar. Televizyon ekranına seçim süreciyle ilgili bir program yansır. Programda sunucunun dışında Başkan'ın Medya Strateji Uzmanı ve Seçim Kampanyası Pazarlama Yöneticisi de vardır. Bu iki uzman, Başkan'ın kitleler tarafından bu ölçüde desteklenmesini kampanyasının gücüne yani anlatının başından beri klişe olarak sunulan reklam filmlerine bağlar. Bu kriz yönetimini bir iş olarak gören ve neredeyse bütün süreci yöneten Motss, bu sözlere oldukça kızar; çünkü Başkan’a olan desteğin artmasında başrolde kendisi ve Brean vardır. Televizyondaki sunucu ekranda bir telefon numarası paylaşır ve izleyicilerin seçim süreciyle ilgili kendilerini aramalarını ister. Motss eline kâğıt kalem alır ve numarayı yazar. Bu sahneden anlaşıldığı kadarıyla Motss, anlatının başından sonuna kadar inşa ettikleri tüm resmi tarihe ve iletişimsel belleğe dönük üretimleri ifşa etmek ve yaptığı bu işle duyulmak ister. Fakat inşa edilen bu resmi tarih, asla duyulmamalıdır. Bu nedenle bir sonraki sahnede Motss'un kalp krizi geçirdiğine yönelik yeni bir gerçeklik inşa edilir ve bu sahte gerçeklik yine resmi bir ağızla medya aracılığı ile haberleştirilir: "Ünlü film yapımcısı Motss evinde havuz kenarında güneşlenirken geçirdiği ani bir kalp krizi sonucunda öldü".

Motss'un ölümü, iletişimsel/kişisel belleğin ölümü olarak değerlendirilebilir. Anlatı boyunca kurgulanmış bir resmi tarih söz konusudur. Bu resmi tarih de iletişimsel, kültürel ve nesneler belleği dolayımından geçirilerek üretilir. Motss, bir iktidarın meşruiyetini ve devamlılığını korumak amacıyla inşa edilmiş resmi tarihin her anını tasarlayan bir eyleyen konumundadır. Aynı zamanda bu sahte gerçeklere ya da uydurma olaylara tanıklık etmiş bir iletişimsel bellektir. Dahası sahnelenmiş bu mizanseni yani resmi tarih yazımını olumsuzlayacak ya da yanlışlayacak alternatif ya da karşıt tarih potansiyeline de sahiptir. Alternatif ya da karşıt tarih, ele alınan anlatıdan hareketle söylenecek olursa söz temellidir. Yazıyı temel alan ve yazı üzerinden üretilen kurgulanmış resmi tarihe karşı anlatıda söz, oldukça önem taşıyabilir. İlerleyen zamanlarda sözlü tarih ekseninde 
ortaya çıkarılabilecek olan bu iletişimsel bellek, var olan iktidar için tehlike arz edebilir; çünkü Motss'un kendi deyişiyle algısı yönetilen insanlara resmi tarihin kurgusal tarafı gösterilerek hakikat anlatılabilir. Amerikan siyasal iktidarı için kurgulanmış resmi tarih, artık hakikatin yerine geçmelidir. Bu nedenle yapımcı ölmelidir. Anlatıdaki yapıntı resmi tarihin söz üzerindeki zaferi, bu ölüm üzerinden metaforik bir biçimde gösterilir.

\section{Sonuç}

Ele alınan araştırma nesnesi iktidar, medya, ideoloji, bellek, gerçeklik ve algı üzerine izleyiciyi düşündürecek önemli veriler sunmasının yanı sıra ABD'nin ve ABD'nin bir yumuşak güç unsuru olarak işlev gören Hollywood'un algı ve rıza yönetiminde başvurduğu birtakım yöntemleri de gözler önüne serer. Bu bağlamda sinematik bu imajların ve filmsel söylemin izleyiciyi eleştirel çerçevede düşünsel bir katılıma yönlendirdiği söylenebilir. Başkanın Adamları filmi, Başkan'ın adının karıştığı bir taciz skandalı temelinde edimselleşen birtakım tek taraflı bilinç üretimine odaklanır. Esasında üretilen bu tek taraflı bilinç üretimi aynı zamanda bir ülkenin resmi tarihine de karşılık gelir. Bu noktada sorulması gereken temel soru şudur: ABD'nin resmi tarihi/ tarihyazımı ile hakikat arasında nasıl bir ilişki söz konusudur? Başkanın Adamları filmi bu soru üzerinde izleyiciyi düşündürtmekte ve üretilmiş sahte gerçekliğe ve uydurma olaylara yönelik birtakım sorular sorulmasına aracılık etmektedir.

Başkanlık seçimlerine az bir süre kala yaşanan taciz skandalı, gündemin seyrinin değiştirilmesine yönelik adımları mecbur kılar. Bu çerçevede mevcut ABD iktidarı, medya algı yönetimi uzmanını ve üretilen gerçekliği daha gerçekgibi kılabilmek adına bir Hollywood yapımcısını devreye sokar. Bu noktadan sonra bu iki uzman, gündemin seyrini dönüştürme adına birtakım taktiklere ve stratejilere başvurur. Bu taktikler ve stratejiler kurgulanmış sahte bir resmi tarihi de inşa etmeye başlar. Bir yapıntı ve inşa olarak yazılmaya başlanan bu resmi tarih, birtakım bellek türlerinin de kurgulanmasıyla mümkün kılınır. Kitlelerin ilgisini istenilen tarafa yönlendirebilmek ve mevcut iktidarın arzu ettiği rızayı üretebilmek/imal edebilmek adına iletişimsel ve kültürel bellek ayrıca nesneler belleği şekillendirilmeye başlanır. Anlatıdan hareketle söylenecek olursa rızanın üretilebilmesi ve kitlelerin arzu edilen minvalde manipüle edilebilmesi için bellek değiştirilmeli ve dönüştürülmelidir. İlk olarak kökten dinci terörist Müslümanların Amerikan rüyasına ve Amerikan yaşam tarzına saldıracağı gibi birtakım bahaneler öne sürülerek Arnavutluk'la kurgulanmış (sadece medya üzerinden) sahte bir savaş çıkarılır. Oryantalist temelli bu düşüncenin kitleler tarafından benimsenmesi kolay olur; çünkü temelde Hollywood, Doğu coğrafyasına yönelik ötekileştirici oryantalist filmsel üretimini sinema tarihinin en başından bu yana hız kesmeden devam etmektedir. Bu çerçevede kökten dinci Müslüman düşüncesi kısa sürede kabul görür.

Kurgulanmış sahte savaşı daha gerçekgibi kılabilmek adına Hollywood tekniklerinden yararlanılır. Hem içerik hem de biçim, sinematik hale getirilir. Kurgulanmış savaşın dışında manipülasyonu kuvvetlendirmek ve kitlelerin ilgisini istenilen yöne çekmek adına başka senaryolar edimselleşir, yapay gündemler ve uydurma olaylar ( $p s u d o$ events) üretilir. Gösteri toplumunun bir gereği olarak kitlelerin benimseyeceği pabuç 
gibi göstergeler tasarlanır, bu bağlamda kahramanlık şarkıları bestelenir ve savaş sloganıyla birlikte bir kahramanlık imgesi üretilir. Sahte resmi tarihin/tarihyazımının inşasında geleneksel medya (gazete, radyo ve televizyon) oldukça önem taşır ve önemli bir rol oynar. İktidar, görüntünün kitlelere yön verme gücünün farkındadır. Bu bağlamda toplumsal algı yönetiminde mevcut iktidar, medyayı toplumsal bir kontrol aracı olarak kullanır. Medya, iktidarın elinde şekillenir. Kitlelerin algısının istenilen yöne doğru yönlendirme ediminde ve bellek üretiminde kurgulanmış haber filmlerinden sıklıkla yararlanılır. Her bir manipüle edilen gerçeklik, medyada yer alır. Bu bağlamda gerçek, medya aracılığı ile üretilen bir şeye dönüşür. Medya, üretilen gerçekliğin kitlelerle buluşabilmesinin en kolay yolu olarak anlatıda yer alır. Bu eksende anlatı, iktidarın medyayla olan derin bağı üzerine izleyiciyi düşünmeye sevk eder.

Sonuç olarak Başkanın Adamları filmi resmi tarihin Amerikan hükümetinin tahakkümü altında ve medyanın da bir araç olarak kullanılarak nasıl inşa edildiği, resmi tarihyazımında iletişimsel ve kültürel belleğin nasıl şekillendirildiği, ayrıca fotoğraf gibi ögelerin de kullanımıyla nesneler belleğinin nasıl icat edildiği üzerine odaklanır. Ele alınan döneme tanıklık etmiş olan insanların iletişimsel ve nesneler belleklerinin iktidarın ideolojisi ekseninde nasıl şekillenebilir ve değiştirilebilir bir şey olduğunun da altını çizer. Bu noktada alternatif ya da karşıt tarih devreye sokulabilir mi sorusu akla gelir. Alternatif ya da karşıt tarih, anlatıdan hareketle söylenecek olursa söz temellidir. Gündelik yaşam içinde yer alan söz yani iletişimsel bellek, resmi tarihin yazımında olumlayıcı ya da olumsuzlayıcı önemli bir güce sahip olabilir. Bu bağlamda Hollywood yapımcısı Motss'un ölümü ile kişisel/iletişimsel bellek ve karşıt tarih arasında bir ilişki kurulabilir. Alternatif ya da karşıt tarih ve bu bağlamda da iletişimsel belleği merkezine alan sözlü tarih üzerine fikir yürütülebilir. Alternatif ya da karşıt tarih ancak o döneme doğrudan tanıklık etmiş iletişimsel bellek aracılığı ile (sözlü tarihin potansiyeli ve gücü burada devreye girer) mümkün olabilir ve eğer resmi tarih üretilmiş bir gerçeklik üzerine bina edildiyse ancak yine kişisel bellek ile yanlışlanabilir. Söz merkezli bir yaklaşımla, gösteri dünyasında üretilen yapıntı tarih ifşa edilebilir. Kişisel belleğin gücünün ve potansiyelinin farkında olan mevcut ABD iktidarı, kurguladığı sahte gerçeklik/resmi tarih karşısında sözü susturmayı tercih eder. Anlatıda inşa edilmiş resmi tarihi ifşa edeceğini söyleyen Hollywood yapımcısı Motss öldürülür, böylece üretilen sahte gerçekliğin bir hakikat olarak resmi tarih içinde güvenli bir şekilde kalması sağlanır.

\section{Kaynakça}

Assman, J. (2001). Kültürel Bellek-Eski Yüksek Kültürlerde Yazı, Hatırlama ve Politik Kimlik. İstanbul: Ayrıntı Yayınları.

Balay, B. ve Ocak, E. (2006). Kameranın Tanıklığı: Sözlü Tarih Çalışmalarında Video Teknolojisinin Kullanılması. A. İlyasoğlu, G, Kayacan (ed.). Kuşaklar Deneyimler Tanıklıklar Türkiye'de Sözlü Tarih Çalışmaları Konferansı. İstanbul: Tarih Vakfı, s. 263-272.

Burke, P. (1993). Overture: The New History, its Past and İts Future. P. Burke (ed.) New Perspectives on Historical Writing. Cambridge UK: Polity Press, pp. 1-24. 
Cameron, J. (Yapımcı) ve Cameron, J. (Yönetmen). (1998). T Menşei ülke: ABD.

itanic [Sinema filmi].

Caunce, S. (2011). Sözlü Tarih ve Yerel Tarihçi. İstanbul: Tarih Vakfı Yurt Yayınları.

Chomsky, N. ve Herman, E. S. (2012). Rızanın Imalatı, Kitle Medyasının Ekonomi Politiği. İstanbul: BGST Yayınları.

Connerton, P. (1999). Toplumlar Nasıl Anımsar? İstanbul: Ayrıntı Yayınevi

Çakır, S. (2006). Sözlü Tarih Projelerinde Yöntemsel ve Etik Sorunlar ve Bu Sorunları Çözme Yolları. A. İlyasoğlu, G, Kayacan (ed.). Kuşaklar Deneyimler Tanıklıklar Türkiye'de Sözlü Tarih Çalışmaları Konferansı. İstanbul: Tarih Vakfı, s. 57-70.

Danacıoğlu, E. (2012). Geçmişin İzleri Yanıbaşınızdaki Tarih Için Bir Klavuz. İstanbul: Tarih Vakfı Yurt Yayınları.

Erdilek, N. (2006). Türkiye'de Göç Araştırmalarında Sözlü Tarih Metodu. A. İlyasoğlu, G, Kayacan (ed.). Kuşaklar Deneyimler Tanıklıklar Türkiye'de Sözlü Tarih Çalışmaları Konferansı. İstanbul: Tarih Vakfı, s. 79-85.

Gökdemir, O. (2014). Tarihyazımında İki Yeni Yaklaşım: Sözlü ve Yerel Tarih. A. Şimşek (ed.). Tarih Nasıl Yazııır? Tarih Yazımı Için Çağdaş Bir Metodoloji. İstanbul: Tarihçi Kitabevi, s. 199-222.

Güngör, N. (2013). IIletişim Kuramlar ve Yaklaşımlar. Ankara: Siyasal Kitabevi.

İlyasoğlu, A. (2006). Yakın Dönemde Tarihe İlginin Farkılışması Sürecinde Sözlü Tarih Alanının Türkiye'deki Gelişimine Bir Bakış. A. İlyasoğlu, G, Kayacan (ed.). Kuşaklar Deneyimler Tanıklıklar Türkiye'de Sözlü Tarih Çalışmaları Konferansı. İstanbul: Tarih Vakfı, s. 15-22.

Kontny, O. (2002). Üçgenin Temelini Yok Sayan Pythagoras: Oryantalizm ve Ataerkillik Üzerine. Doğu Batı Yayınları, 20, 117-134.

Kyvıg, D. E. ve Marty, M. A. (2011). Yanıbaşımızdaki Tarih. İstanbul: Tarih Vakfı Yurt Yayınları.

Lehane, S. ve Goldman, R. (1977). Oral History in Undergraduate Research. The History Teacher, $6(1), 47-50$.

Lippman, W. (1997). Public Opinion. New York: The Free Press.

McCombs, M. E. ve Shaw, D. L. (1995). The Agenda Setting Function of Mass Media. O. BoydBarrett, C. Nwebold (ed.). Approaches to Media, A Reader. First Published: Arnold, pp.153-164.

Merz, J. T. (2000). A History Of European Thought in The Nineteenth Century Chapter I: Introductory. England: The Continuum International Publishing Group.

Metin, C. (2002). Sözlü Tarih ve Türkiye'deki Gelişimi. Türk Kültürü, 469, 288-298.

Mutlu, E. (2004). İletişim Sözlüğü. Ankara: Bilim ve Sanat.

Neyzi, L. (2013). Ben Kimim? Türkiye'de Sözlü Tarih, Kimlik ve Öznellik. İstanbul: İletişim Yayınları.

Oğuz, M. (Yapımcı) ve Irmak, Ç. (Yönetmen). (2008). Issız Adam [Sinema filmi]. Menşei ülke: Türkiye.

Okumuş, F. (2014). Sinema Tarih Yazımı: Türk Sineması Tarihyazımı Için Yöntem Arayışı. Ankara: 


\section{Gece Kitaplığı.}

Öztürk, S. (2013). Türkiye'de Sinema Mekânlarını Sözlü Tarih Üzerinden Anlamak. Milli Folklor, 98, 19-31.

Öztürk, S. (2010). Türkiye'de Sözlü Tarihten İletişim Araştırmalarında Yararlanma Üzerine Notlar. Milli Folklor, 87, 13-26.

Öztürk, S. (2010). Elektronik Kültürün Adamına Karşı Yazılı Kültürün Adası: Issız Adam Filmine İletişim Sosyolojisi Açısından Bakmak. Marmara Iletişim Dergisi, 16, 201-216.

Öztürkmen, A. (2011). Sözlü Tarihin Poetikası: Anlatı ve Gösterim. B. Ünüvar (ed.). Edebiyatın Omzundaki Melek: Edebiyatın Tarihle İlişkisi Üzerine Yazılar. İstanbul: İletişim Yayınları, s. 53-62.

Portelli, A. (1991). The Death Of Luigi Trastulli and Other Stories. Albany: State University of New York Press.

Said, E. (1978). Orientalism. New York: Vintage Books.

Said, E. (2008). Şarkiyatçılık. İstanbul: Metis Yayınları.

Şahin, Ö. (2004). Geçmiş, Tarih ve Sözlü Tarih. Mülkiye, XXVIII(244), 111-126.

Thompson, P. (2006). 21. Yüzyılda Sözlü Tarih İçin Potansiyeller ve Meydan Okumalar. A. İlyasoğlu, G, Kayacan (ed.). Kuşaklar Deneyimler Tanıklıklar Türkiye'de Sözlü Tarih Çalışmaları Konferansı. İstanbul: Tarih Vakfı, s. 23- 38.

Thompson, P. (1999). Geçmişin Sesi Sözlü Tarih. İstanbul: Tarih Vakfı Yurt Yayınları.

Tosh, J. (2013). Tarihin Peşinde. İstanbul: Tarih Vakfı Yurt Yayınları.

Van Dijk, T. (2000). Opinions and Idologies in the Pres. A. Bell, P. Garrett (ed.). Approaches to Media Discourse. Massachusetts: Blackwell, pp. 21-63.

Yüceer, S. (2005). Tanıkların Anlatılarıyla Bursa Tarihi Sözlü Tarih Arşivi 1919-1938. Bursa: Bursa Üniversitesi Basımevi. 